\title{
Organizational Innovation Instrument to Industry: Focusing in the U Theory
}

\author{
Lucas Moreira de Souza ${ }^{1}$, Raul Afonso Pommer Barbosa ${ }^{2}$, Artur Virgílio Simpson Martins ${ }^{3}$ \& Flavio de São Pedro \\ Filho $^{4}$ \\ ${ }^{1}$ Academic at the Department of Administration, Federal University of Rondônia, Brazil. PIBITI/CNPq, Brazil \\ ${ }^{2}$ Administration at Getulio Vargas Fundation FGV-EAESP, Federal University of Rondonia, Brazil \\ ${ }^{3}$ Administration at Universidade Federal do Paraná, Instituto Federal de Rondônia, Brazil \\ ${ }^{4}$ Management and Economics from the University of Beira Interior (UBI), Covilhã, Portugal. PPGA/UNIR, Brazil \\ Correspondence: Raul Afonso Pommer Barbosa, Administration at Getulio Vargas Fundation (FGV-EAESP), \\ Federal University of Rondonia, Brazil.
}

Received: June 2, 2020

Accepted: July 9, 2020

Online Published: July 19, 2020

doi:10.5430/ijba.v11n4p67

URL: https://doi.org/10.5430/ijba.v11n4p67

\begin{abstract}
This study highlights the organizational innovation practices of a glass processing plant, in order to promote radical change in the assumptions of Theory $\mathrm{U}$. The question to be answered is how Theory $\mathrm{U}$ can be used to develop the innovative system of an organization. The overall objective of this research is to study an organization's effort to innovate from the standpoint of its employees; and to achieve a specific interpretation of a production system by (1) improving, and (2) describing how Theory $\mathrm{U}$ can be used for organizational innovation, before (3) proposing a model of innovation for the organization under study. The qualitative and quantitative research is developed by the Case Study Method. It involves raising the awareness of employees working in the organization to highlight management's planning efforts, in order to improve their organizational and pro-innovation behavior. The main result is a technical treatment of the management of the production system, in order to induce organizational innovation. It prioritizes the construction of an innovative model, with Theory $U$ as a working tool. In addition, it is found that organizational innovation requires participatory planning. Operational success requires the employees to be wholeheartedly committed to improvement and constantly offering suggestions in order to contribute to organizational change; this maintains a vision that sustains competitiveness; The results allow us to offer an innovation model that prioritizes employees' perceptions and break away from outdated behavior based on top-down industrial structure, in which the directors monopolize the decisions that restrict teams of workers to routine tasks.
\end{abstract}

Keywords: management, organizational innovation, industry, production, Theory U

\section{Introduction}

This research is the result of studies related to organizational planning in a glass-making factory; we focused on organizational innovation from the perspective of radical change driven by the assumptions of Theory $\mathrm{U}$. This investigative work is justified by the significance of academic intervention to improve industrial performance, using the perceptions of employees as a normal route to changing practice. Moreover, there is no doubt that the factors which promote innovation can be identified through a survey that identifies the pro-innovation conditioning elements. This argument lets us consider the following research question: How can we apply theoretical principles to develop a factory's innovative system? Addressing this question is the general objective of studying the pro-innovation efforts of an organization faced by its employees' awareness; the specific results that we seek require (1) a survey of the perceptions of the employees of this organization, (2) describe how the Theory $\mathrm{U}$ can be used for organizational innovation and (3) propose a model of organizational innovation in this case. The present document first reviews the topics and subtopics in theoretical and conceptual terms and then prepares the next stage, following the logic of results which were previously obtained.

\section{Theoretical-Conceptual Approach}

The $\mathrm{U}$ theory is the basis of this research, since the production process of the factory under scrutiny is operated by employees. Evidence of this was observed in the first technical visit to the organization. Through a conceptual view, 
the limited self-knowledge and self-perception of individuals working in the routines in the system can be transcended. The new perspective induces the development of abilities and skills that can ascertain the changes required and carry them out. Following the recommendations of Scharmer (2010) in his Theory U, this can be treated as a learning experience. He conceives the application of possible tools for innovation and transformation in the cognitive process of those involved, which conduce to behavioral change oriented to the construction of operative talents,

The planning of organizational change is desirable for developing the means that target innovation, always in compliance with the designs from management that allow the changes to be made. Following universal precepts, the administrative planning process in general, and especially that related to innovation, should be constructed in two stages. Reading Chiavenato (2014) clearly indicates that the process starts with an organizational diagnosis; Here, the elements located on the outside of the production process, such as the agents with their techniques and strategies, come to engage with the objectivity and fairness that the respondents want and can only secure through change.

The elements belonging to the group which has a strategic vision and does not operate within the production process are shown in Figure 1. The group aims to modify the vision and objective to a strategic level and want less to operate the current production process.

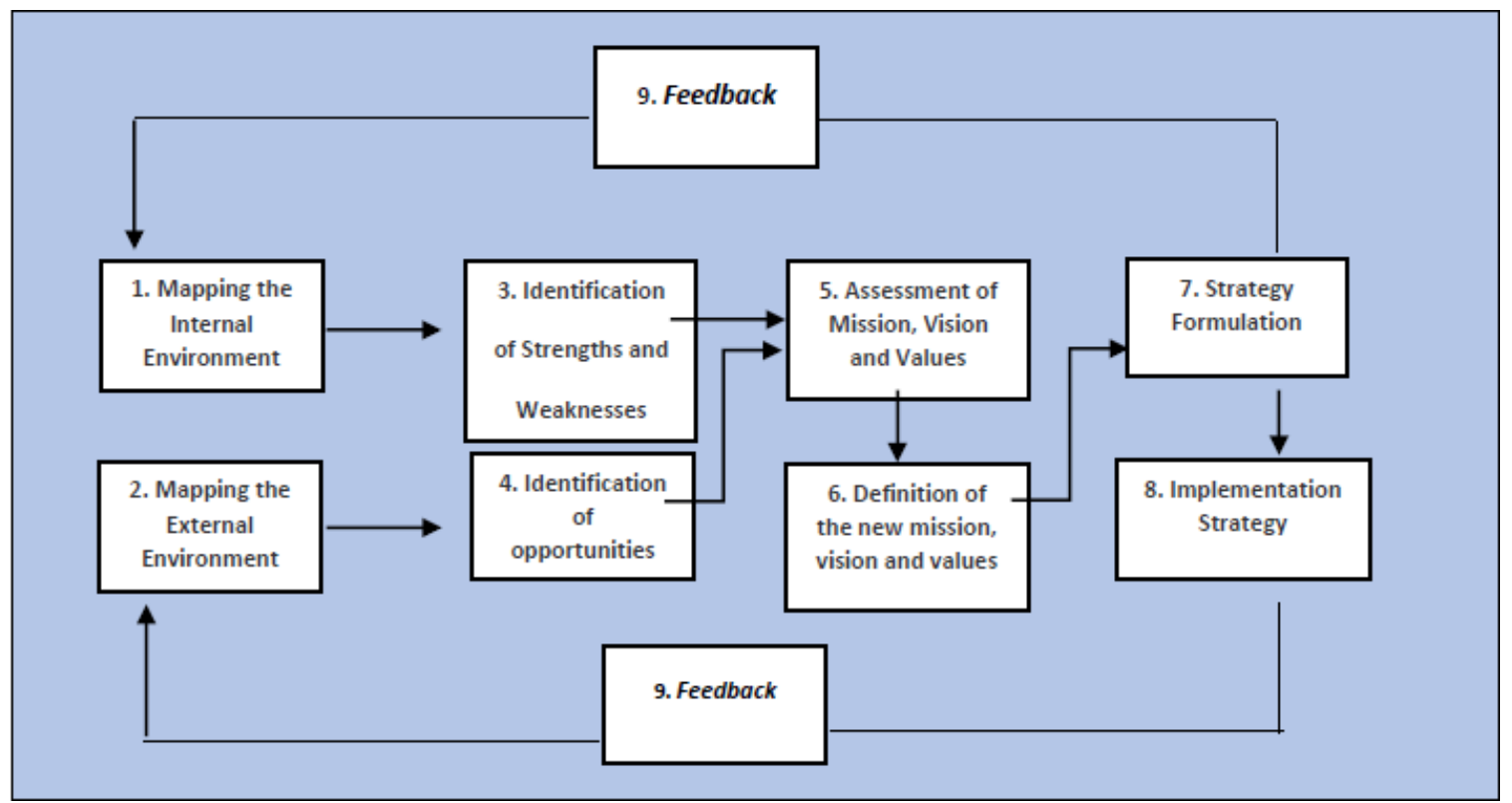

Figure 1. The steps in the organizational strategy process

Fonte: Prepared on the basis of Chiavenato (2014).

Table 1 . The steps in the organizational strategy process

\begin{tabular}{ll}
\hline Organizational strategy procedures & Descriptive procedures \\
\hline $\begin{array}{l}\text { 1. Mapping the internal } \\
\text { environment }\end{array}$ & $\begin{array}{l}1.1 \text { Research on the internal environment clarifies their strengths and } \\
\text { weaknesses. }\end{array}$ \\
\hline $\begin{array}{l}\text { 2. Mapping of the external } \\
\text { environment }\end{array}$ & $\begin{array}{l}2.1 \text { The procedure to map the external environment lets the organization } \\
\text { better understand its competitors as well as the factors beyond its } \\
\text { domain field. }\end{array}$ \\
\hline $\begin{array}{l}\text { 3. Identification of internal factors: } \\
\text { Strengths and Weaknesses }\end{array}$ & $\begin{array}{l}3.1 \text { The feature that distinguishes this from the previous planning stage } \\
\text { is the fact that the organization finds within it the relevant information } \\
\text { on the actions that it seeks to change. }\end{array}$ \\
$\begin{array}{l}\text { 4. Identification of external factors: } \\
\text { opportunities and threats }\end{array}$ & $\begin{array}{l}4.1 \text { The opportunities and threats are external factors over which the } \\
\text { organization has no control; it cannot integrate them into the }\end{array}$ \\
\hline
\end{tabular}


macro-environment in which the organization operates.

\begin{tabular}{ll}
\hline 5. Evaluation of the mission, vision & $\begin{array}{l}5.1 \text { The mission, vision and values allow the organization to learn and } \\
\text { and values }\end{array}$ \\
present to society what its purpose is, where it wants to reach and what \\
its assumptions and organizational values are.
\end{tabular}

6. Definition of the new mission and 6.1 The previous phase of evaluation is to determine whether the mission new goals and the objectives that the organization has are consistent with the business conditions.

7. Strategy Formulation 7.1 This should integrate resources, people, and the various areas of work with a view to promoting the common interests of the organization.

8. Implementation of the strategy $\quad 8.1$ Implementing the strategy is a simple procedure that requires all the stakeholders and the resources used in the organization to be involved in the task of integration.

\begin{tabular}{llll}
\hline $\begin{array}{l}\text { 9. Feedback information } \\
\text { Feedback }\end{array}$ & or $\begin{array}{l}\text { 9.1 From the feedback information about the success or failure of the } \\
\text { strategy can emerge and managers can be in charge of any needed } \\
\text { adjustments. }\end{array}$
\end{tabular}

Source: Prepared by the authors on the basis of Chiavenato (2014b).

\subsection{Concepts of Production Planning}

The literature suggests that for the design of an industrial operation to occur in a planned manner, its needs should determine the key features in the creation of products, as well as the configuration of services, as proposed by Slack, Chambers and Johnston (2018). Moreover, the implementation of these activities needs to be monitored and so does the meeting of customers' demands. Thus, these authors consider that there are branches that complement each other in production and operations processes for managing organizational resources effectively; for example, managing physical capacity and the inventory, and the use of corporate planning systems such as Enterprise Resources Planning (ERP), which are enterprise resource management systems. For these authors, the efficient management of production resources initiates the production processes of the lean philosophy; here, procedures are aimed at reducing inventory levels and overall resources, but maintaining the quality of products and services through a new philosophy of production.

\subsection{Concepts Theory $U$}

Theory U was designed by Scharmer (2010); it aims to set future conditions as it emerges. The movement of the U set in this theory is the descent of the individual to his true self, through opening, observing, feeling, witnessing, crystallization, prototyping and performing. Through these steps, people can turn around and deconstruct one self to build a new one in order to achieve their best personal and professional performance. This can be incorporated into manufacturing, because it derives from possible outcomes in this process.

As Nascimento (2015) sees it, Theory $U$ is a change management model to be implemented in any type of organization through the knowledge and revelation of the true self of each employee in the organization. Therefore, this theory provides the basis for changing the present self to an 'I refurbished', which Scharmer (2010) considers the true self. These arguments are focused on deep social values such as love of one's neighbour, social responsibility and a leadership vision shared among the members of the organization. It incorporates a new work-force with their ideals, collective efforts and joint construction, next to each other in an organization that is turned to face a future of shared responsibility.

Writers suggest that the experience of applying the Theory $U$ to an industrial context should provide the incentive for innovation and improvement within organizations. Scharmer (2010) indeed points to the existence of levels in organizational change, the deepest being one that affects the inside of the institution. The author points out the methods of organizational learning that address the institutional management of external change as a reaction and resetting for new purposes; in this case it involves foreign judgments, familiar to those who think a change in Presencing is the highest level of profound change. Here, the individual's ability to invoke potential arises from involving an open mind, body and soul in changing a building as it emerges. Figure 2 shows the steps in a diagram of this U theory. 


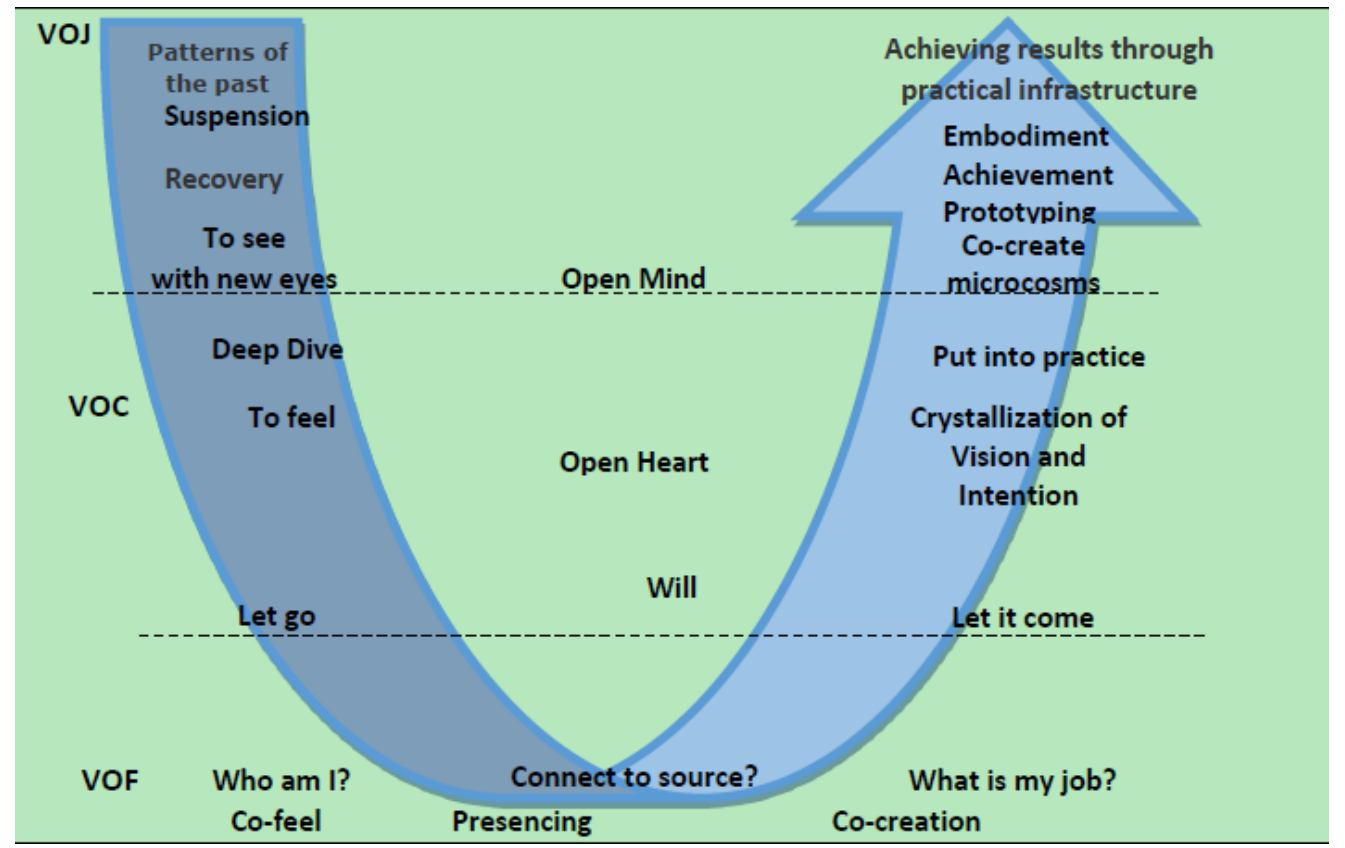

Figure 2. Steps in U Theory

Source: Adapted by the authors of Scharmer (2010).

Table 2. Steps in U Theory: description of Figure 2

\begin{tabular}{ll}
\hline Inflection point & Descriptive procedures \\
\hline 1. Suspension & $\begin{array}{l}\text { 1.1 Suspend trials in order to be able to view the objective conditions faced by the } \\
\text { individual, including numbers and basic facts. }\end{array}$ \\
\hline 2. View & $\begin{array}{l}2.1 \text { The vision is the beginning of seeing a problem with new eyes, that is, differently } \\
\text { from that to which we are accustomed. Thus, new answers can be obtained to } \\
\text { questions that already exist. This new view lets us experience deeper discoveries in a } \\
\text { social field. }\end{array}$
\end{tabular}

3. Deep Dive

4. Feeling

3.1 Scharmer (2010) conceives a deep dive as a process of searching the deepest origins or essential human values, which are the basic assumptions that we rarely perceive as true.

4.1 Feeling is changing the deep dive state to a state where feeling, thought and action condense inside the psyche of the subject to a situation where it needs to let go of the obstacles that hinder the realization of the deep feeling.

\section{Letting go}

5.1 Identification of models is used, which influence internal (at first seemingly caused by preceding forces alone). In this step we let go of the old model and start to make an individual connection with the intentions of a higher order.

\section{Presencing}

6.1 The combination of feeling and witness connects us now with a source of high potential in the future. When we move to the state of Presencing, perception of a future possibility that depends on us to make it come true starts to be realized.

\section{Leave come}

7.1 Threshold of an upward path leading to the viewing space and crystallizing intent, which is to anticipate what is new in the future that seeks to emerge; the new direction is external to the interior way of seeing.

\section{Crystallize}

8.1 Crystallizing means clarifying the vision and intent of the highest future possibility. The difference between normal and crystallization processes is imagination; crystallization comes from the deepest place of knowledge and the self, 
since imagination can come from almost anywhere, even from recovery.

9. Putting into practice $\quad 9.1$ The development of an interior way of seeing transforms the inner vision of the external action; at this stage where prototypical living microcosms explore the future by doing - putting the new into practice.

\section{Prototyping}

10.1 The prototype is the first step in exploring the future by doing and experimenting. It allows learning and adapting to give feedback in a fast cycle.

\begin{tabular}{lll}
\hline 11. embody & & $\begin{array}{l}\text { 11.1 Transformation of the new in stock, infrastructure and practices; incorporating } \\
\text { the new in the context of co-developing larger ecosystems. }\end{array}$ \\
\hline $\begin{array}{l}\text { 12. VOJ } \\
\text { Voice) }\end{array}$ & (Judgment & $\begin{array}{l}12.1 \text { The old and limiting patterns of judgment and thinking. Without the ability to } \\
\text { shut down or suspend VOJ, we cannot access our creativity and reach the deepest } \\
\text { level of the U shape. }\end{array}$ \\
\hline $\begin{array}{l}\text { 13. VOC } \\
\text { Cynicism) }\end{array}$ & (Voice on & $\begin{array}{l}13.1 \text { Emotional disconnection, in such forms as cynicism, arrogance and coldness } \\
\text { which prevent us from diving into the depths around us. }\end{array}$ \\
\hline 14. VOF (Fear Voice) & $\begin{array}{l}\text { 14.1 The fear of letting go of our familiar selves and the world that we know; the fear } \\
\text { of going forward, of surrendering to nothingness. }\end{array}$
\end{tabular}

Source: Prepared by the authors on the basis of Scharmer (2010) and Nascimento (2016).

\subsection{Concepts of Innovation}

Sousa and Monteiro (2015) define innovation as the main element of an organization. They see it as the ability to insert new technologies and enhance products and processes so as to improve competitiveness in the market. Innovation is vital for organizational development, but it needs measures to control the pace and intensity by which it occurs. As these authors state, it is important to measure the DNA of innovation and to define accurately the set of ideas, practices and knowledge that make an organization innovative enough to compete in the market, as reflected in the research applied by the present investigation. The visual element chosen here is called Innovation Radar; it is a representative multi-tool presenting the 12 main locations of innovation, as shown in Figure 3 below.

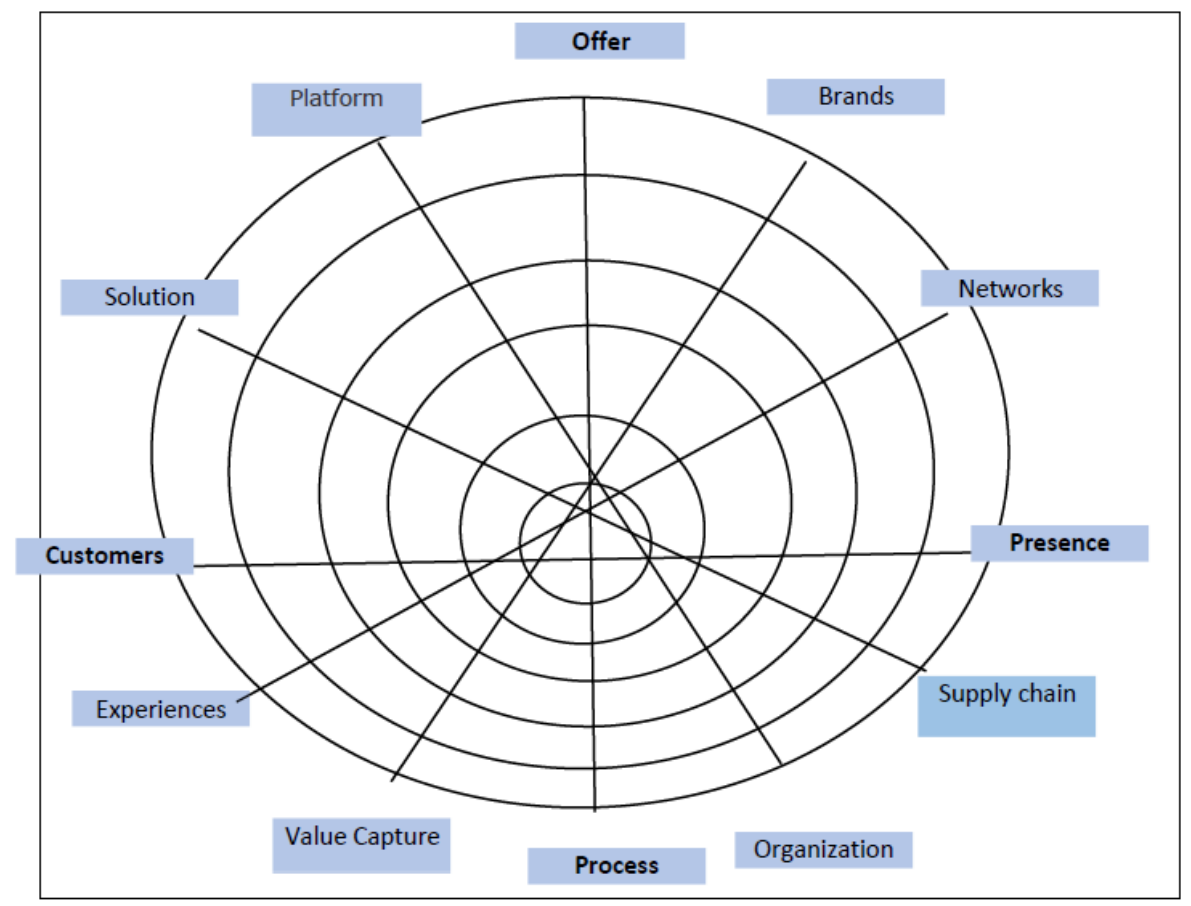

Figure 3. Innovation Radar

Source: Adapted by the authors from Sawhney, Wolcott and Arroniz (2006, p. 77) cited by Carvalho et al, 2014. 
Table 3. Elements of innovation radar

\begin{tabular}{|c|c|}
\hline $\begin{array}{l}\text { The } 12 \text { elements of } \\
\text { the radar } \\
\text { Innovation }\end{array}$ & Description of innovative typologies \\
\hline 1. Offer (what) & 1.1 involves creating new products or services. \\
\hline 2. Platform & 2.1 involves the use of common components or blocks to create different products. \\
\hline 3. Solution & 3.1 understands the creation of integrated and customized offerings. \\
\hline 4. Customer & 4.1 includes the discovery of new customer needs or the identifying of unserved segments. \\
\hline 5. Experience & 5.1 covers any point of interaction (contact) with the customer. \\
\hline 6. Value & 6.1 includes the discovery of new customer needs or identifying unserved segments. \\
\hline 7. Process (How) & 7.1 covers mainly increased performance processes. \\
\hline 8. Organization & 8.1 involves changes in shape, function or the scope of the company's activities. \\
\hline 9. Supply Chain & $\begin{array}{l}9.1 \text { involves changes in the chain, such as the flow of information, and outsourcing } \\
\text { relationships. }\end{array}$ \\
\hline 10. Presence & 10.1 comprises mainly new distribution channels and new points of presence. \\
\hline 11. Networking & $\begin{array}{l}11.1 \text { mainly involves the use of information and communication technologies integrated } \\
\text { with the offerings. }\end{array}$ \\
\hline 12. Brand & xpansion of the brand into new domains. \\
\hline
\end{tabular}

Source: Adapted by the authors from Carvalho et al, 2014.

The operation of any one of these 12 innovative typologies is developed through the Local Innovation Agent Program (ALI) SEBRAE applying Innovation Radar. Carvalho et al describe a programme in which members of the National Scientific and Technological Development Council (SEBRAE) developed field studies from the survey and application forms, which tabulated statistical data in SPSS (IBM SPSS Statistics 21), to quantify the efforts of innovative organizations of Brazil's industrial regions. They assigned scores from 1 to 5 in their research on various industries such as furniture-making, computer science, and various others and manipulated these data to show the locations and grade the innovations of the companies concerned.

To direct this study to a typology of innovation, we introduce the concepts of organizational innovation proposed in Tigre (2014). He proposes a form of coordination between different areas in a company and its relationships with customers and suppliers in order to innovate the company's branches and business processes.

Sousa and Monteiro (2015) differentiate two stages of the innovation process. For these authors, the first stage should be to mentally conceive the innovation process and the second to implement the conception. The factors involved in organizational development and change, make it difficult to reconcile the relations between them and also to ensure healthy relationships between the employees committed to carrying out such tasks successfully; this difficulty comes from the alter ego of individuals, their vanities, resistance to change and tendency to seize the status quo and its benefits.

The intent behind implementing organizational innovation demonstrates a need for what Chiavenato (2014b) calls the organizational communication process, a key element in enhancing creativity, where each member of the community can contribute new insights that should be added to the innovation process. For creativity to expand and for employees to be committed and confident that they will not be ridiculed or dismissed, Sousa and Monteiro (2015) highlight the stimulus element in the design process and also the power to create conditions whereby development is seen as an action to be performed by managers. Both the creation of a favourable environment for the generation of new ideas and aligning them with corporate interests can give the organization a competitive advantage over its rivals.

Tigre (2014) suggests that two significant distinctions can be made in the research related to organizational innovation. The first involves technical terminology and production technologies; and the second turns on operational matters in the inventions required in favour of innovation. Terminological distinctions may involve organizational investment within its capabilities, involving knowledge when employees work with basic cognitive tools for improvement, resulting in organizational productivity. In the case of industrial organizations, where innovation leverages the 
production process, incremental inventions often result in patents, since they focus on breakthrough discoveries that affect various business sectors. They require profound changes in the organizational environment, emphasising the platforms, systems, and methods, products and processes that have been installed, reaching deeply into a heavily saturated market. Tigre adds that innovation has been observed to apply not only to the modification of methods of organizing production management, but also to organizational change management processes and administrative systems, the first of which is e subject of this study.

\section{Methodology}

Santos (2015) defines the methodological framework of scientific activity as a set of methods that allow facts and phenomena to be systematically investigated. In order to achieve its purpose, the characteristics that define the scientist's activity are problem formulation, research planning, data collection, systematic analysis of the information and conclusions reached in a systematic and reproducible manner. Marconi and Lakatos (2017) define the importance of scientific methodology for differentiating the accumulated experiences of the past, knowledge of which can be called common sense, from knowledge that is repeatable, proven and tested, with a scientific cast that makes it different from empirical knowledge. Yet scientific knowledge has an empirical component that should not be ignored. However, it is treated together with solid theory underlying or refuting the empirical demonstration. This phase is known as testing. Figure 4 in an illustrative diagram shows the elements that compose the methodological construction of an investigative study.

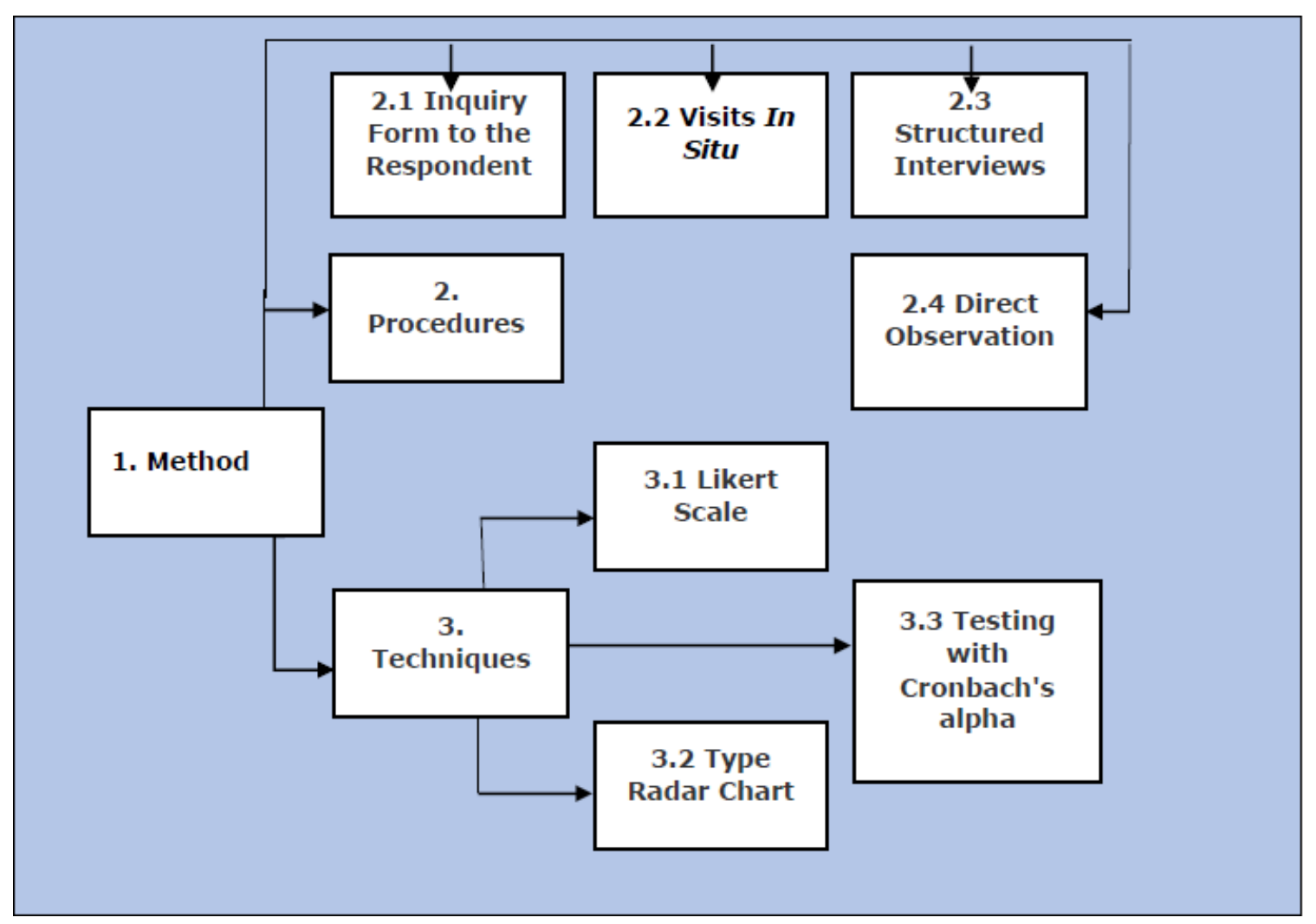

Figure 4. Methodology in applied research

Source: Prepared by the authors. 
Table 4. Defining the parts of Figure 3: methodology in applied research

\begin{tabular}{|c|c|}
\hline $\begin{array}{l}\text { Technical } \\
\text { procedures }\end{array}$ & Descriptive procedural \\
\hline 1. Methods & $\begin{array}{l}\text { 1.1 Marconi ( } 2017 \text { th) shows that the use of scientific methods to solve everyday problems } \\
\text { is possible, but scientific research cannot be built without the use of scientific method. }\end{array}$ \\
\hline 2. Procedures & $\begin{array}{l}\text { 2.1 The procedures of research, as Marconi and Lakatos (2017b) note, are the steps or } \\
\text { series of actions that should be taken in some combined form to achieve the research } \\
\text { objectives. }\end{array}$ \\
\hline 3. Techniques & $\begin{array}{l}\text { 3.1 The techniques in reading and understanding, according to Lauro Prodanov (2013), are } \\
\text { the technical means used to achieve or the general purposes of scientific research. }\end{array}$ \\
\hline $\begin{array}{l}\text { 4. Consultation } \\
\text { Form to the } \\
\text { Respondent }\end{array}$ & $\begin{array}{l}\text { 4.1 This form is used when the researcher wishes to obtain further answers and details. As } \\
\text { Santos indicates (2015), the form is used as a guide for interviews and is very close to an } \\
\text { open questionnaire. }\end{array}$ \\
\hline $\begin{array}{l}\text { 5. Structured } \\
\text { interviews }\end{array}$ & $\begin{array}{l}\text { 5.1 The interview is a research procedure or instrument used frequently in organizational } \\
\text { studies; Santos (2015) defines interview structure as a tool that standardizes the questions } \\
\text { put to all respondents. }\end{array}$ \\
\hline 6. Visit in situ & $\begin{array}{l}\text { 6.1 The visit in situ is a technical procedure performed within the organization's task } \\
\text { environment with the aim of offering the researcher the opportunity to establish direct } \\
\text { contact with the interviewee(s). }\end{array}$ \\
\hline $\begin{array}{l}7 . \\
\text { observation }\end{array}$ & $\begin{array}{l}\text { 7.1The work of Marconi and Lakatos (2017b) describes direct observation as a research } \\
\text { technique that aims to look at, explore and describe phenomena and surroundings, } \\
\text { understanding the processes being enacted and the interpolations between people and their } \\
\text { situations in order to identify problems. }\end{array}$ \\
\hline 8. Scale Likert & $\begin{array}{l}\text { 8.1 The Likert scale as Cooper and Schindler (2016) describe it is used to calibrate } \\
\text { statements expressing favourable or unfavourable attitudes towards some object of } \\
\text { interest; each respondent agrees or disagrees with the statement and the intensity with } \\
\text { which s/he does so can be noted by a degree on the scale. }\end{array}$ \\
\hline 9. Radar Graphic & $\begin{array}{l}\text { 9.1 Radar charts are charts that display multivariate data in the form of a two-dimensional } \\
\text { chart of three or more quantitative variables represented on axes that start at the same } \\
\text { point. }\end{array}$ \\
\hline $\begin{array}{l}\text { 10. Cronbach Alpha } \\
\text { Test }\end{array}$ & $\begin{array}{l}10.1 \text { Cronbach's alpha test consists of applying a test from the alpha coefficient to measure } \\
\text { the consistency of elaborate assertions in a form and validate them or not through the } \\
\text { result of the determination. This must be greater than } 0.700 \text { to indicate that the assertions } \\
\text { are consistent. }\end{array}$ \\
\hline
\end{tabular}

Source: Prepared by the authors on the basis of survey data.

\subsection{Regarding the Method}

The method provides the rationale of the research; in the understanding of Prodanov (2013) it allows the researcher to establish general rules to differentiate between scientific and non-scientific goals. Methods are developed with a certain degree of abstraction, allowing the researcher to decide on the scope of the research, the explication of the rules governing the facts and the validity of their generalization. For this author, referring to the method can attest to the technical and mental operations that enable scientific research to be constructed.

The method reported in the present paper is that of a case study. As recommended by Santos (2015), it is the most suitable for research involving situations, problems and applications for solving problems in organizations. The feature that makes it appropriate method in this case is the depth to which one or a few facts can be analyzed to obtain the largest possible amount of detailed information about the object under scrutiny. As Cooper and Schindler (2016) imply, a case study is a research method that combines individual and group interviews with the analysis of records and observations. Researchers who use it can extract information from multiple sources such as reports, brochures, and notes written or unwritten and can combine their interpretation of the data from interviews with 
employees in order to get multiple perspectives on a single organization, situation, event or process delimited in time and space. Case study methodology can be used to understand specific processes. Cooper and Schindler (2016) hold that in the business and management area, the results from a case study can be used to experiment with modifications of a new process of product development or with the selection of windows and placement processes to generate high value transactions. Case study methodology can be used to understand specific processes.

\subsection{Procedures}

Marconi and Lakatos (2017b) allow us to conceptualize the procedures as set means that researchers can use to collect and correlate data from different sources. By taking these actions, data can be collected in a direct or indirect mode: in the former, the respondent is led by a previous agenda or script to questions on a respondent consultation form (i.e. a questionnaire) that s/he must answer. In this research the main procedures adopted were to visit in situ, to observe and to ask each respondent stakeholder to complete a questionnaire that had open and direct questions.

\subsection{Techniques}

The research techniques, accepting the theoretical assumptions of Lakatos and Marconi (2017), can be understood as the way that research deals with data. Combining techniques allows us to obtain specific results for each object, which is why such investigating instruments as Excel software were used to achieve the research purposes. Other instruments were the application form, the Likert Scale and the validation of the form by testing for Cronbach's alpha.

\section{(I) Software Excel Application}

The technical application with Excel Software was to tabulate the data collected from the Likert-scaled answers to the questionnaire, and to reduce the data to a statistical series of incidence percentages. Part of the contribution was to compile an overall index. In the descriptive Excel program on its platform in the 2013 version, the importance of this type of chart is reported. It can show relative values to a central point and can also represent categories that are not directly comparable.

\section{(II) Treatment by Likert Scale}

The Likert scale is an instrument that can measure the perception of an individual or group of respondents on a number of assertions, to each of which respondents must indicate their value judgment, which varies in the intensity of the impressions that they report: the number 1 represents either the highest possible score or total rejection of the assertion. 2 means partial disagreement and 3 means neither acceptance nor rejection of the assertion. The remaining options, 4 and 5, reveal positive impressions made on the respondent, the number 4 standing for partial agreement and the number 5 for entire agreement with the assertion.

(III) Test Technique in Cronbach's alpha

The test in Cronbach Alpha is performed by statistical software and allows researchers to assess the consistency of the statements made in a statistical model showing the sum of notes as more than 0.700 and therefore validated as consistent. The test consisted of 15 assertions on a Likert scale with an intensity somewhere between 1 and 5 and ascribed to a total population of 30 individuals. A score was obtained of 0.905 in the consistency of the statements, a result which is more than sufficient to demonstrate that the elaborate assertions were consistent. Table 5 shows the result of the verification test of affirmative consistency by Cronbach's Alpha.

Table 5. Test statement by Cronbach's alpha

\begin{tabular}{ll}
\hline Cronbach's alpha & $\begin{array}{l}\text { Cronbach's alpha based on Number of Items } \\
\text { standardized items }\end{array}$
\end{tabular}

\begin{tabular}{lll}
\hline $\mathbf{0 . 9 0 5}$ & 0.906 & 15
\end{tabular}

Source: The authors, on the basis of survey data.

Table 5 shows the results of Cronbach's alpha test, where the value of the upper limit is 1.000. Respondents registered their agreement or disagreement with 15 assertions on a validly formed Likert scale by assigning scores ranging from 1 to 5. The average value among the responders was 3.6 and the most frequent value was 3.77 in response to assertions number 11, 12 and 15 . Higher values of 4.20, 4.37 and 4.53 were respectively associated with assertions numbered 1, 4 and 8 . They show stronger agreement, ranging from partially agree to strongly agree. 


\section{Planning Improvements Based on Theory $U$}

The industrial plant is a franchise and has a staff of 150 , including officers, managers and operational workers. Projects of this nature have pre-programmed financial results for a year as in previous studies and any investment in machinery and equipment should be matched by enough money to exceed the cost of the investment. As the literature on Innovation Management suggests, innovation can arise from the implementation of organizational innovation systems, which are characterized by changes to methods, systems, processes, tasks, and other organizational activities intended to innovate in or through the organizational environment so that fresh procedures may occur.

To make the necessary changes in the production platform, the actions that concern the machinery and the elements must be differentiated from those that will affect the staff. Improvements must be preceded by the participation of people in the production process and its value to the organization. Theory $\mathrm{U}$ requires people to take part in planning the actions and business strategies that aim to reach the desired level of excellence.

\subsection{Organizational Planning In View of Employees}

Planning is the activity program by which future activities will be carried out; thus it can maximize the effect of organizational actions. Shared planning should be the starting point for deep organizational change because, as Figure 5 shows, the perceptions on the respondents' Consultation Forms indicate that it should by their Likert scores. The results shown in this Figure can be interpreted as reporting the opinions of employees on the importance that the organization gives to their participation in the formulation and implementation of its business strategy.

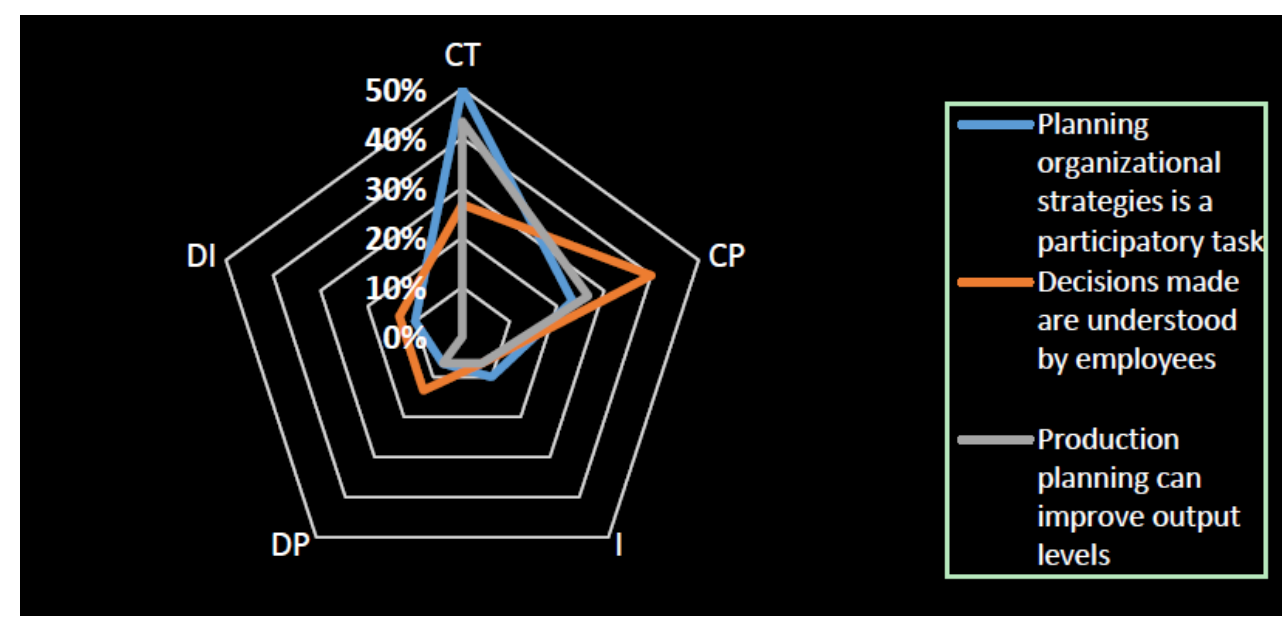

Figure 5. Organizational planning

Source: Prepared by the authors on the basis of survey data.

The statement outlined in blue in Figure 5 refers to the perception among the respondents of the planning of organizational strategies. It is a participatory task and it corresponds to $50 \%$ of full agreement among the 30 respondents who were asked about it. Here, 15 employees felt that this statement corresponded to their everyday organizational experience. It is also true that agreement with the assertion reached a level of more than $70 \%$ of the respondents if we include partial agreement with the statement, for a total of 22 respondents declared a positive perception of it. Another $10 \%$ of the respondents as shown in Figure 3, were not in the category of positive or negative but were indifferent to this claim, and $6.66 \%$ of the responses matched the perception of two employees who to some extent disagreed the claim, plus $10 \%$ who totally rejected it. This created a percentage of 16.66 who disagreed with the assertion that the planing of organizational strategies is a participatory task. These results indicate the possibility that collective participation creates competitive advantage in implementing organizational change; we found less resistance to the idea from employees since the results were generated from the consensus between employees and managers.

The assertion illustrated in orange in Graph 1 that the firm's decisions are fully understood by these reviewers outlines a notable qualitative characteristic, demonstrated by the percentage of employees who totally agree with it: 
$26.66 \%$ of the total population of respondents, corresponding to 8 persons. At the same time, the affirmative group that demonstrated a perception in partial agreement was $40 \%$ of the total number of respondents, that is to say, 12 persons, the largest group of respondents. There remained a total of two people who were indifferent to this statement, $6.66 \%$ of the total; this was the smallest group, in contrast to the groups which agreed or disagreed. The dissenting portion of the statement was equal in number and percentage making it a partially significant extent; more than a quarter of the total who did not understand all or even some of the decisions of their firm's top management. This dissentient group was divided into two subgroups: those who disagreed to some extent and those who strongly disagreed, each of these consisting of 4 employees out of the sample of 30 individuals represented. Calculated as a percentage of the total, each group amounted to $13.33 \%$, so the total group size of 8 was the equivalent of $26.6 \%$.

The third statement illustrated by a colour cell in Figure 1 aimed to highlight the degree of agreement or disagreement among employees in their perception that any kind of production planning can increase the output levels. To interpret this, outlining a total of $43.34 \%, 26.66 \%$ agreement and a partial correlation caused the positive perception of this assertion by 21 employees, representing $70 \%$ of the total responses. If we adding to these data $6,66 \%$ of neutral responses representing the perception of two respondents, the latter percentage is equal to the number of respondents who filled out the respondent consultation form in the field who disagreed to some extent. 'This is partially distinct from those who chose the option 'strongly disagree'; 5 employees did so, $16.66 \%$ of the total.

\subsection{The Application of the Theory $U$ to Reality Investigated}

The goal of this research was the development of a socio-technical system capable of implementing change, so that the people and technologies housed in the labour market could converge through the better use of individual potentials. This would entail employees' understanding of their true role in the organization, and the way in which they could improve their work every day beyond the previous day's results. These individuals should also collaborate with suggestions for changes that are not noticed even though they coexist in space; in this way, the organization would be continuously improved by adopting a system designed to tackle and manage all the necessary changes by using the right mechanism to approach the firm's current situation.

This study found through field research that the organization needed to change before it could reach organizational excellence and could adopt some changes that would increase its financial profits or improve its visibility in the society of Rondonia. It was explained when the information was being collected that the organization belongs to a franchise, making it difficult to implement immediate changes in its organizational structure. The improvements suggested here may be subject to the owner's approval and would have to be sent to the franchise matrix to obtain the franchiser's advice.

The amendments necessary to increase productivity and efficiency and organizational effectiveness are ones that allow the workplace to grow through organizational reform in the same physical space. The machinery and bulky items such as equipment and other tangible resources could be arranged better, and this would allow the organization in question to increase its profitability and the financial returns that motivate these investments. However, a preliminary study of economic and financial feasibility should first be made to assess whether the desired investments would correspond to the expected return. It would be better to examine these improvements carefully before the managers of the firm concerned.

It can be inferred that increasing the amount of resources produced through the planned investments can generate in the organization a high volume of waste in the form of metres of glass. The organization at the time of this research did not have a system for recycling waste except under an agreement with stakeholders who collected this material and reused in their routine activities, giving it a specific purpose. No profitable organization has to fund waste collection by additional resources. These results imply that the organization should adjust the volume of resources that it plans to dispose of in losses of geometric glass. The resulting glass production process would produce a win-win relationship with these collectors of vitreous materials. It would reduce the cost of removing the material, relieving the organization of all additional expense in this regard.

It was found that organization under study had no R \& D sector in its structure, not even a specific part of the innovation area. Thus these activities depended on the matrix information transfers to the branch being studied. Hence, they should strengthen their interaction with the university to updated their knowledge of organizations and the market in order to provide their managers with the tools and techniques available to their competitors, resulting in a rich organizational culture and interactivity that could adapt the nuances of marketing and making these useful informational tools available for corporate decision making. 
In order to implement the necessary organizational changes, the firm should focus on tasks in innovative situations where the human element is the main agent. It is understood that only employees can operate all the required changes, for future defensive situations. This will be taken as a starting point in the journey to radical transformation such as will reach the organizational levels of profitability desired by managers. The concepts of Theory $U$ hold that these degrees of radical change and transformation can be achieved through the real me,

A suggestion has also been made that concepts from sustainability are incorporated in an attempt to implement a model intended for collectors of geometric glass waste and the collectors' associations. This measure in itself, proves that change is possible and also desirable, but for it to occur the slow and bureaucratic actions materialized through contracts between franchise and franchisees must be withstood in order for these concepts to start to compose the culture of the organization and thus internalize the culture of change. Indeed this will not occur unless this culture is internalized so deeply that it becomes a basic assumption shared by the entire organization, as is already the case with organizations that act on environmental concerns.

The $\mathrm{U}$ Theory from the most basic concept of deconstructing and reconstructing human and social values to the most profound is revealed as a tool capable of introducing all the necessary changes, but it cannot do this unless its methodology is known and applied by all the members of the social body of which it is a part inside a highlighted series. Managers, employees and even their own franchise system must become aware that this tool can transform the current situation to a future emergent one, that is, to a world that rebuild itself all the time. If this occurs, there would seem to be no limits to organizational change in size or degree.

To illustrate the intervention that has been studied, Figure 6 shows a diagram supported by the study that investigate the industrial breeding and selected precepts of Scharmer's Theory U (2010). This Figure represents a suggested improvement on this investigative study.

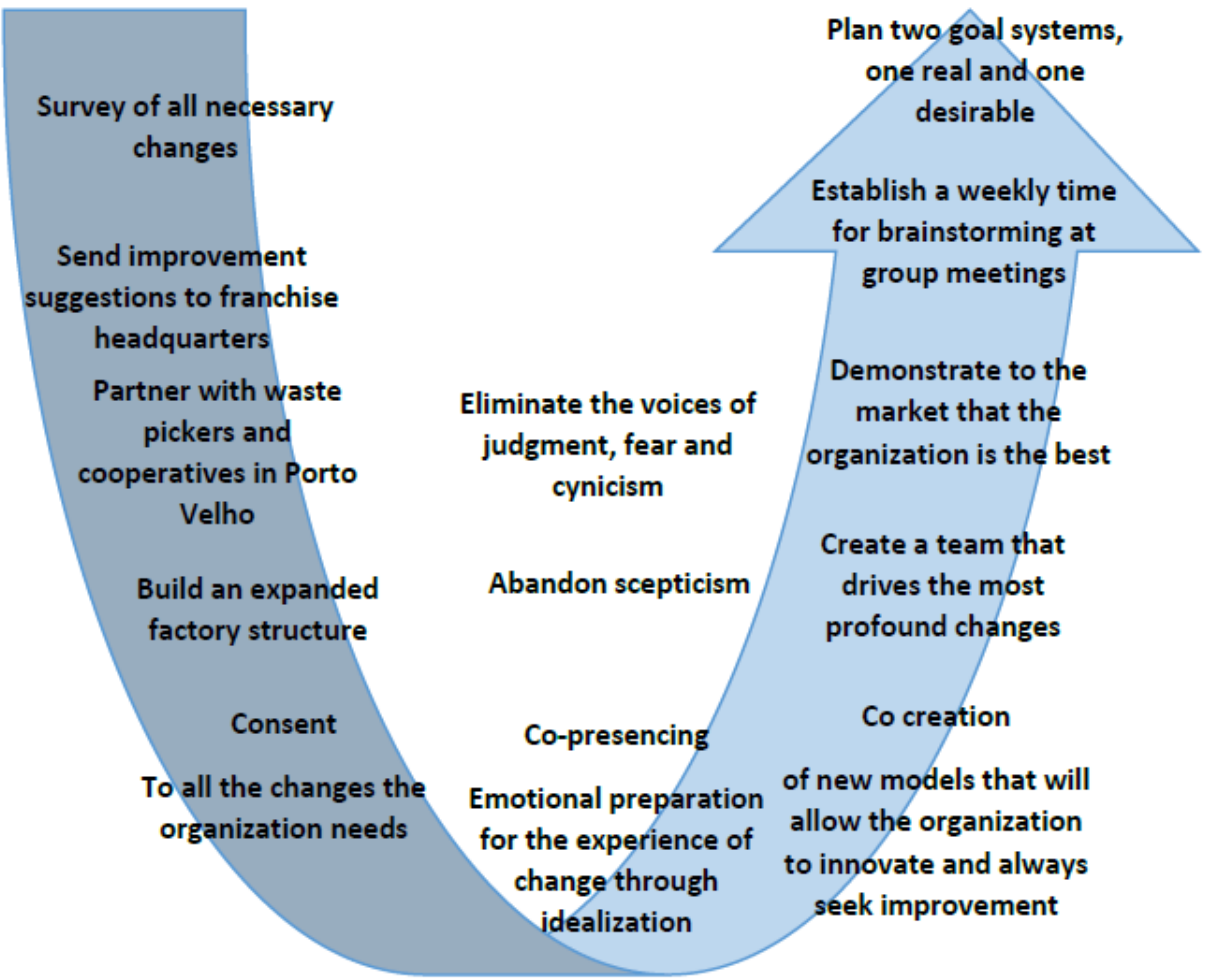

Figure 6. Theory $\mathrm{U}$ applied to the glass processing industry.

Source: Prepared by the authors on the basis of the survey data. 
Table 6 describes each of the components of Figure 6 that intervene in the organization under study under a proposal for improvement that managers should plan with the participation and involvement of collaborative groups. This would yield a greater number of observations to consider.

Table 6. Theory $\mathrm{U}$ applied to the glass processing industry.

\begin{tabular}{ll}
\hline Feature to be implemented & Descriptive of the realities faced in the unit under study \\
\hline $\begin{array}{l}\text { Addressing the recycling of waste } \\
\text { materials }\end{array}$ & $\begin{array}{l}\text { When the interviews were conducted it was found that some employees } \\
\text { were reluctant to grant the possibility of making changes and complained } \\
\text { about the impact changes can cause. }\end{array}$ \\
\hline Listing all necessary changes & $\begin{array}{l}\text { There are needs that managers may not be aware of, to control the financial } \\
\text { results of the organization. However, those who operate the glass production } \\
\text { system every day take note of them. }\end{array}$ \\
\hline $\begin{array}{l}\text { Sending fuggestions for } \\
\text { improvement to the franchise matrix }\end{array}$ & $\begin{array}{l}\text { The suggested changes should be sent to a resolution of the Franchise } \\
\text { Council to consider and accept }\end{array}$ \\
\hline $\begin{array}{l}\text { Partnering collectors and waste } \\
\text { cooperatives in Porto Velho }\end{array}$ & $\begin{array}{l}\text { The industry has evidence of products that simultaneously increase } \\
\text { productivity and generate a surplus that must be collected as waste without } \\
\text { generating costs. }\end{array}$
\end{tabular}

Building an expanded industrial The increase in productivity in the workplace is an investment scheduled to structure meet the expected demand and requires the industrial park to be expanded.

Experiencing in advance all the The human side of change must be felt in order to raise in each employee the changes that the organization needs feeling that s/he can improve and that the collective body made up of the members must be cohesive.

Co-presencing emotionally prepared Co-witnessing the changes made, through a collective experience, will for the experience of change through prepare people to support the changes in their comfort zone requiring idealization witness, i.e. it will modify the deeper mental structures to engender the internalization of deep change.

Co-creation of new models that will The generation of new ideas depends on organizational models that allow the organization to innovate encourage the organization to improve and innovate continuously. and always seek improvement Organizational innovation and improvement involve studies of organizational systems but require less investment than technological innovation and so should be encouraged.

Create a team that drives the most The management of change will be preceded by learning how to prepare all profound changes employees in the factory to deal with teammates and encourage them to exhibit new behaviors.

Demonstrate to the market that the To increase a firm's market share, consumers must be told about the organization is the best advances that are being made and the way that these make a firm more attractive than its competitors.

Establish a weekly time for the The top-down view of changes limits the perception of them to the reports of production of ideas from group managers, which does not solve the problems experienced by the operators meetings of the production process. An alternative proposal is to institutionalize the practice of revealing ideas.

Plan two goals systems, a real one If two goal systems are set up, one for those who value the results of the and a desirable one process through changes estimated annually and another for those who want the organization to maintain the status quo, then management can check how urgently the identified changes are needed.

\begin{tabular}{ll}
\hline Abandon scepticism & $\begin{array}{l}\text { Doubt and questioning about the importance of the work dry up the flow of } \\
\text { suggestions that can add to the organization, so it is necessary to believe that } \\
\text { such suggestions are important. }\end{array}$
\end{tabular}

Eliminate the voices of judgment, The major obstacles to establishing an effective change of culture in the fear and cynicism organization are fear, cynicism and the fear of judgment.

Source: Prepared by the authors on the basis of the survey data. 
It is understood from Theory $\mathrm{U}$ that intervention in organizational reality requires training and emotional preparation, but these must be sought through the revelation of the deepest human values: an open will, an open heart and an open mind.

\subsection{The Organizational Innovation and Improvement Strategy}

Figure 7 outlines the perceptions of the 30 respondents who filled out the consultation form. This means that the three assertions that were put to the respondents have a higher concordance of $60 \%$, indicating that innovation is a constant in the organization. However, the perception of partial correlation is greater than that of total agreement on two of the three assertions; this gives a new structure, unlike the structure of the earlier graph of the same type, which shows the complete agreement that was felt by an absolute majority.

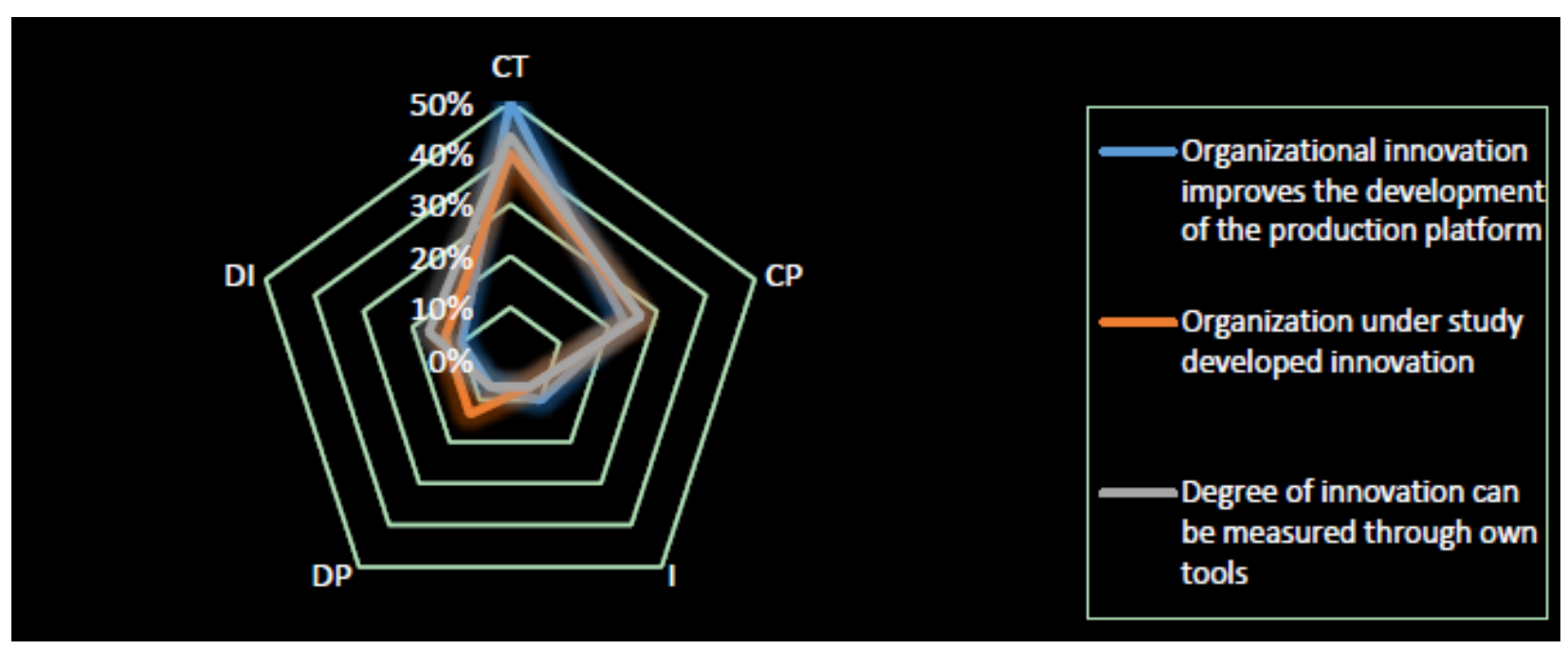

Figure 7. Innovation in the organization

Source: Prepared by the author on the basis of survey data.

The statement outlined in blue is the perception of organizational innovation and the power to develop the productive platform among the employees who responded. This received a response of $73.33 \%$ in agreement; half of the responses, 15 out of a total of 30, totally agreed that it improved a firm and 7 people, $23.33 \%$ of the remainder registered partial agreement with this view. The highlighted statement also showed that 3 respondents, $10 \%$ of the whole, were indifferent in their perception of it, and a further $10 \%$ completely disagreed. The final group of 2 , indicating their partial disagreement, represented $6.66 \%$ of all the responses, bringing the number of dissentient employees up to 16 .

The assertion which states that the organization developed innovation lately received the agreement of $66.66 \%$ of he respondents, divided between full agreement (felt by 12 people (40\%) and partial agreement obtained from 8 employees (26.66\%), b These numbers can be interpreted to mean that the organization id indeed develop innovation lately, since the total sample population was drawn from all sectors of the company and so the collective perception reflects the view prevailing across it. A minority of 2 was indifferent to the assertion, while the share of respondents who disagreed with it was $26.6 \%$, equivalent to 8 persons.

The degree to which the assertion that current innovation can be measured by the use of proper tools is valid is demonstrated by the shape of the grey outline in Figure 3. According to 18 respondents who completed the respondent consultation form, corresponding to $70 \%$ of the total population, this statement applies. The division of the responses in the data is $43.33 \%$ for total agreement and $26.67 \%$ for partial agreement, the numbers of respondents being 13 and 08 respectively. Two respondents remained indifferent to the claim and 2 partially disagreed that the statement corresponded to their own view, each of these occupying $6.66 \%$ of the total of replies, $13.33 \%$ together, which links these two minor responses with the index responses. Other respondents totalled 5 $(16.66 \%)$. 
The strategy of making improvements as a means of implementing changes observed on the day in the organization under study meets the skills literature on this specific theme in Correa (2017) and Slack (2013),. They see this practice as typical organizational innovation. It has the possibility of building a new organizational structure through shared planning, a review of methods and processes and the replacement of obsolete practices by incremental changes deriving from observations made by employees at all levels of the firm, which does reflect the practices of organizational innovation.

\section{Conclusion}

This research as a qualitative and quantitative case study showed the advantage of studying the case unit in depth and combining procedures of various types. Were conducted observation spot, multifocal group analysis, and tabulation of the data in the software Excel to create Radar graphs. To validate the depth of agreement with the assertions among the respondents, we used Cronbach's alpha test among others. These together allowed our study to become intensive enough to cover various facets of the firm that was investigated. Thus, study became more rigorous by combining various complementary tools and concepts. The difficulty of carrying out such a study is that it may not repeat the results of similar research, because the investigated entity typically differs from any other subject and therefore the peculiarities of one organization are not found in any other. We also consulted research on applying Theory $\mathrm{U}$ in different entities.

In response to our research problem on how to apply theoretical principles and develop the innovative system of a factory; we concluded from the results the use of the theoretical model of the $\mathrm{U}$ Theory used in this article and using the validated statements. The instruments used in this research can be replicated in similar or correlated research, for instance, inquiry forms can be distributed to respondent and the same formulas can be used to analyze the efficiency, effectiveness and organizational competitiveness. Many instruments can capture data on the investigated objects.

The combination of qualitative and quantitative tools increased the depth of this case study, because they help to absorb as much information as possible, despite the absence of management reports recording productivity and of the participation of similar companies operating in other regions through the franchise system, Therefore, it cannot be said that the success of an organization analyzed in regard to its market share and low level of waste is the same as or greater than the success of others. Hence, it is recommended that similar studies that use the case study method to research franchises should compare the data from to the reporting unit to those available from the management report or through direct contact with the matrix to find the productivity rates of these companies. Another mechanism that research like this can use is to monitor the implementation of the suggestions developed in the research process, which, a priori, is sometimes an uncertain task.

\section{References}

Andrade, M. M. D., \& Maria, L. E. (2017). Investigative Techniques. São Paulo: Editora Atlas.

Andrade, M. M. D., \& Maria, L. E. (2017). Scientific methodology. São Paulo: Editora Atlas.

Bastos, T. P. (2014). Innovation management, the economy of technology in Brazil. Rio de Janeiro: Editora Campus Elsevier.

Correa, H. L., \& Correa, C. A. (2017). Production and Operations Management: Manufacturing and Services: A Strategic Approach. São Paulo: Atlas.

Cristiano, P. C., \& Cesar, F. E. (2013). Methodology of scientific work: methods and techniques of research and academic work. Novo Hamburgo: Feevale.

Donald, R. C., \& Schindler, P. S. (2016). Research Methods in Management. Porto Alegre: AMGH.

Estevam, S. I. (2015). Manual Methods and Scientific Research Techniques. Niterói: Impetus.

Idalberto, C. (2014). Administration in modern times: the new horizons in management. Barueri: Manole.

Idalberto, C. (2014b). Organizational Behavior: the dynamics of the success of organizations. Barueri: Manole.

Nascimento, N. T. A. (2016). Organizational innovation focusing on Theory U: Case study in a rural educational institute. Master's Thesis in Public Administration, Federal University of Rondônia. Porto Velho.

Nigel, S., Brandon-Jones, A., \& Johnston, R. (2013). Principles of Production Management. São Paulo: Atlas.

Nigel, S., Brandon-Jones, A., \& Johnston, R. (2018). Production Administration. Translation Daniel Vieira. São Paulo: Atlas.

Otto, S. C. (2010). Theory U: how to lead by perception and realization of the emerging future. Rio de Janeiro: Elsevier.

Sousa, F. C., \& Sparrow, M. I. (2015). Collaborate to innovate: The organizational and social innovation as a result of the decision process. Lisboa: Syllabus Issues. 